\title{
НАПРЯМИ РОЗВИТКУ СИСТЕМИ МЕДИЧНОЇ ОСВІТИ В УКРАЇНІ: ПОГЛЯД У МАЙБУТНЄ
}

\author{
Yu. V. Voronenko \\ Shupyk National Medical Academy of Postgraduate Education, Kyiv \\ DIRECTIONS OF MEDICAL EDUCATION SYSTEM DEVELOPMENT IN \\ UKRAINE: FUTURE OUTLOOK
}

Метою даної роботи є концептуальне обгрунтування моделі підготовки медичних кадрів в Україні. Робота побудована на статистичних даних МОЗ України із застосуванням методів концептуального узагальнення та соціального моделювання.

Визначено проблеми підготовки медичних кадрів, що існують у всьому світі і в Україні, наприклад: невідповідності між компетенціями, потребами і фінансами; географічні і професійні дисбаланси медиків на ринку праці; гендерна стратифікація по спеціальностях; кадрове домінування стаціонарної допомоги над первинною; професійний сепаратизм із великою кількістю спеціальностей тощо.

Запропоновано низку концептуальних першочергових заходів, які стосуються змін у законодавстві та направлені на: улагодження взаємовідносин між ВНЗ та практичними закладами охорони здоров’я; введення ліцензування медичної практики; удосконалення системи кількісної оцінки безперервного професійного розвитку; введення резидентури; якісної підготовки управлінців та фахівців за спеціальністю “Громадське здоров’я”; оптимізації спеціальностей та підготовки лікарів в інтернатурі тощо.

Соціальними наслідками втілення концептуальних складових моделі підготовки медичних кадрів в Україні прогнозується не тільки значне підвищення якості підготовки професійних медичних кадрів, а й забезпечення європейського вектора розвитку держави. Робота є оригінальною.

Ключові слова: підготовка медичних кадрів; реформа вищої медичної освіти.

The aim of this work is the conceptual reasoning of medical personnel training model in Ukraine. The paper is based on the statistical data provided by the Ministry of Health of Ukraine with usage of conceptual generalization and social modeling methods.

The problems of medical personnel training, which exist in the whole world and in Ukraine, for instance, such as: incompliances between the competences, needs and finances; geographical and professional imbalances of doctor on labor market; gender stratification on specialties; personnel dominance of hospital care over primary one; professional separatism with a great number of specialties are determined.

The number of conceptual urgent events, which concern changes in legislation and directed to settle the relations between Universities and practical healthcare facilities; to implement the licensing of medical practice; to improve the system of high-quality assessment of continuous professional development; to implement the residency; high-quality training of "Public health" managers and specialists; to optimize specialties and doctors internship training are proposed.

The social consequences of conceptual contents of medical personnel training model implementation in Ukraine predict not only sufficient increase of professional medical personnel training quality, but also providing the European vector of state development. The work is original.

Key words: medical personnel training; higher medical education reform.

Вступ. Проблема медичних кадрів останніми роками набула транснаціонального рівня. Так, у країнах Євросоюзу дефіцит лікарів вже наближається до 230 тисяч, що в півтора раза більше, ніж число усіх лікарів, працюючих в Україні. Цей чинник діє як потужний стимул до еміграції кадрів 3 України [1].

Але глобальна криза кадрів не обмежується лише їх нестачею. Існують невідповідності між компетенціями, потребами і фінансами. $€$ географічні і професійні дисбаланси медиків на ринку праці.
Розвивається гендерна стратифікація по спеціальностях. Є кадрове домінування стаціонарної допомоги над первинною [2]. Не зменшується професійний сепаратизм: кількість спеціальностей в Україні досягла майже 130, причому є такі, за якими взагалі ніхто не працює.

В Україні сьогодні відбуваються активні процеси із забезпечення європейського вектора розвитку держави. Осторонь не залишається й система підготовки професійних медичних кадрів. Провідні фахівці з організації медичної освіти протягом

(C) Ю. В. Вороненко 
останніх років розробили низку концептуальних пропозицій щодо удосконалення системи вищої медичної освіти та безперервного професійного розвитку лікарів та провізорів.

Мета роботи - обгрунтувати модель підготовки медичних кадрів в Україні.

Основна частина. Робота побудована на статистичних даних МОЗ України із застосуванням методів концептуального узагальнення та соціального моделювання.

Всесвітня федерація медичної освіти виділяє три етапи підготовки медичних працівників. Після додипломної освіти відбувається післядипломне навчання в інтернатурі, резидентурі чи на циклах спеціалізації, де отримують власне спеціальність. Наступна фаза - безперервний професійний розвиток - освіта, яка триває все життя. Близькими до цієї універсальної лікарської моделі є схеми підготовки медичних сестер, фельдшерів, парамедиків, провізорів, фармацевтів, військових медиків. Кожен із трьох освітніх процесів передбачає постійне вдосконалення, усунення накопичених невідповідностей [3].

Центральне місце в підготовці лікаря обіймає інтернатура. Адже саме тут вперше здобуваються спеціальність та право на практику. Водночас в Україні за півстоліття свого існування інтернатура вже стала надто проблемною.

Основні фактори цієї проблемності:

1. Інтернатура перестала бути власне інтернатурою, тобто формою підготовки лікарів лише за базовими спеціальностями. 3 учорашніх випускників готуються зразу нейрохірурги, урологи, клінічні онкологи й інші вузькі спеціалісти.

2. Порушується принцип справедливості у виборі професії для усіх випускників медичних ВНЗ. Одна категорія випускників - так звані бюджетні студенти - навчаються в інтернатурі здебільшого на сімейного лікаря, терапевта, патологоанатома і на інші непрестижні професії. Друга ж категорія випускників, так звані студенти контрактної форми навчання, у т. ч. далеко не з кращими результатами навчання, проходять інтернатуру за більш престижними спеціальностями і стають дерматологами, акушерами-гінекологами, урологами. Це призводить до збільшення кількості лікарів вказаних спеціальностей, що викликає небажаний тиск на ринок праці.

3. Тривалість та якість підготовки лікаря не відповідають сучасним європейським вимогам. Для якісної підготовки лікарів необхідно забезпечити відповідні умови, але це дуже ресурсомістка система. Прагнення багатьох ВНЗ зробити модерні симуляційні навчальні комплекси не виключають необхідності працювати у клініках. На Заході це, як правило, університетські та муніципальні лікарні, які спільно з кафедрами готують кадри. В Україні виконання загальнодержавної функції, завдання національної безпеки, фактично блокується фінансовими органами та місцевими адміністраціями. Ініціюються десятки судових процесів, примушуючи ВНЗ перейти виключно на умови оренди, а не на співпрацю за нормами Господарського і Цивільного кодексів. А там, де ще вдається співпрацювати, допуск клініцистів кафедр до хворих є обмеженим.

Ще одним проблемним напрямком $є$ кадрове питання: в Україні 2/3 усіх лікарів працює лише за 16 базовими спеціальностями - як правило, на I-II рівнях медичної допомоги. Разом з тим, тільки третина лікарів працює за рештою 111-ма вузькими спеціальностями.

Згідно з розробленою концепцією, пропонується залишити в інтернатурі лише основні спеціалізації. Для спеціальностей $з$ медицини та педіатрії їх 12: акушерство та гінекологія; анестезіологія; внутрішні хвороби; хірургія; медицина невідкладних станів; патологічна анатомія; психіатрія; фтизіатрія; судово-медична експертиза; загальна практика - сімейна медицина; педіатрія; дитяча хірургія. За Міністерством охорони здоров'я може бути закріплена функція визначення квот по кожній із цих спеціалізацій та розподілу їх між ВНЗ. Вступ до інтернатури повинен бути конкурсним, для забезпечення рівних прав і для тих, хто навчається за бюджетні кошти, і тих, хто навчається за кошти юридичних та фізичних осіб.

Вибір професії для спеціалізації в інтернатурі за бюджетні кошти повинен залежати від якості навчання і відповідної перемоги у конкурсі ВНЗ. Крім того, випускники дво-трирічної інтернатури можуть повністю забезпечити I і II рівні надання медичної допомоги.

Ще однією проблемою є те, що в Україні законодавчо введена резидентура, але цей вид навчання ще не реалізований. На Заході резидентура триває до 5 років. Така модель для України не нова, оскільки за схожими принципами побудована клінічна ординатура, яка зарекомендувала себе на високому рівні і користується широким попитом, у т. ч. серед іноземців. Саме клінічна ординатура може стати 
прообразом резидентури як форми індивідуалізованої, штучної підготовки фахівця з персональною відповідальністю за якість.

За оцінками розробників концепції, близько $25 \%$ лікарів після інтернатури можуть за електронним конкурсом вступити до ВНЗ у резидентуру. Повинен бути реалізований прозорий та справедливий вступ на виділені МОЗ України бюджетні місця по кожній із 47 високотехнологічних спеціальностей. Очікується, що випускники дворічного навчання в резидентурі разом із випускниками інтернатури забезпечать надання до 95 \% всіх видів медичної допомоги в країні.

Найчастіше в розвинених країнах підготовка фахівців за спеціальністю “Громадське здоров'я” $\epsilon$ двохетапною. Спочатку в університетах протягом до 4-х років готуються бакалаври із загальної спеціальності “Громадське здоров’я”, які після випуску працюють на посадах помічників фахівців. А власне професіонали за різними спеціалізаціями громадського здоров'я, такими, як управління охороною здоров'я, епідеміологія, біостатистика, біобезпека і гігієна, мікробіологія і вірусологія, готуються на магістерських програмах ще до двох років. Така модель $є$ цілком прийнятною і для України.

Сьогодні в Україні діє декілька півтора-дворічних навчальних програм для підготовки управлінців для сфери охорони здоров'я: 1) для державних службовців; 2) для соціогуманітарної сфери; 3) для сфери охорони здоров'я півторарічна програма для керівників закладів третинного рівня, що розроблена за допомогою фахівців ЄС. Тільки в НМАПО імені П. Л. Шупика пройшло чотири випуски із загальною кількістю 70 осіб, але із них працює на посадах третинного рівня менше половини, оскільки на даний час ще не розроблено потрібних кваліфікаційних вимог. Ми вважаємо, що поки не створені освітні стандарти, треба терміново ввести доповнення до кваліфікаційної характеристики відповідного керівника, інакше ці спеціалісти будуть не потрібними. Що ж стосується проходження спеціалізації з основ управління охороною здоров'я лікарями медичних закладів первинного рівня та 3 метою реалізації права займатися приватною лікарською практикою, то для цього достатньо існуючої двомісячної спеціалізації.

Лишається складним питання підготовки за іншими понад 60-ма спеціальностями, котрих немає ні в інтернатурі, ні в резидентурі. Частина з них є необхідною для системи охорони здоров'я, наприклад: УЗД, дієтологія, ендоскопія тощо. За цими спеціальностями можуть продовжувати готувати фахівців на циклах спеціалізації або в перспективі - в резидентурі. Частину спеціальностей, як ми вважаємо, на сьогодні можна скоротити. Наприклад, лікар із суднової медицини, лікар із авіаційної і космічної медицини, лікар із дослідження хімічних факторів довкілля тощо.

Ми пропонуємо інноваційну структуру 4-5-річної післядипломної освіти лікарів в Україні: інтернатура, потім для бажаючих резидентура та цикли спеціалізації. Така трьохетапна модель є результатом вивчення та імплементації досвіду багатьох країн Європи і США. Модель є гнучкою і дозволяє бажаючим завершати освіту та йти працювати після кожного етапу, а не вчитися всім без перерви ще по 4-5 років після закінчення ВНЗ. Водночас для високотехнологічних спеціальностей розробниками врахована норма Директиви ЄС щодо тривалості навчання до 5 років.

Окремим важливим питанням $є$ процеси безперервного професійного розвитку (БПР). Необхідність навчання лікаря протягом його професійного життя у світі $є$ аксіомою. В Україні система БПР існує вже багато років, але на законодавчому рівні офіційно цю дефініцію не визначено та немає стандартів для різних категорій медиків. Пропонуємо ввести професійне ліцензування кожного лікаря при отриманні ним нової спеціальності замість архаїчних кваліфікаційних категорій, які давно втратили свою стимулюючу функцію. Для продовження дії ліцензії необхідно кожні п’ять років проводити атестацію з урахуванням щорічно накопичених лікарем навчальних кредитних балів, а для моніторингу БПР - створити систему електронних портфоліо. До ліцензування доцільно залучати громадські професійні об'єднання.

Необхідно також осучаснити перелік і значимість різних форм підвищення кваліфікації: крім традиційних передатестаційних циклів та тематичного вдосконалення, враховувати акредитовані майстер-класи, тренінги, самоосвіту через дистанційні освітні ресурси, в тому числі й зарубіжні.

Висновки. Ми переконані, що запровадити запропоновані пропозиції цілком реально. Серед першочергових заходів необхідно: 1) концептуально схвалити напрями розвитку медичної освіти; 2) до проекту Стратегії розвитку системи охорони здоров’я в Україні включити медичну освіту окре- 
мим розділом, де передбачити розробку і прийняття низки законодавчих і підзаконних нормативних актів та вказати етапність запровадження змін у медичній освіті відповідно до схваленої Концепції; 3) найближчим часом законодавчо вирішити проблему клінічної підготовки медичних кадрів на базах лікарень. Треба передбачити саме поняття клінічної бази ВН3, особливості ї̈ фінансування із двох різних бюджетів та визначити механізм співпраці із закладами охорони здоров'я, де розташовані кафедри.

\section{Список літератури}

1. Савинкина Л. А. Проблема дефицита медицинских кадров и пути ее решения / Л. А. Савинкина, Т. С. Шепелова // Современные проблемы науки и образования. - 2014. - № 6; URL: https://www.science-education.ru/ ru/article/view?id=16466 (дата обращения: 30.03.2017).

2. Beck A. H. The Flexner report and the standardization of American medical education / A. H. Beck // The Journal

\section{References}

1. Savinkina, L.A., \& Shepelova, T.S. (2014). Problema defitsyta meditsynskikh kadrov i puti yeyë resheniya [The problem of medical personnel deficiency and the lines of approach]. Sovremennyye problemy nauki i obrazovaniya Contemporary Science and Education Problems, 6. Retrieved from https://www.science-education.ru/ru/article/ view?id=16466 [in Russian].
Вважаємо, що розроблені концептуальні складові моделі підготовки медичних кадрів в Україні $€$ цілком реальними до втілення найближчим часом, що дасть можливість не тільки значно підвищити якість підготовки професійних медичних кадрів, а й забезпечити європейський вектор розвитку нашої держави.

Процеси удосконалення системи підготовки медичних кадрів потребують постійного супроводу з урахуванням динамічних змін світових вимог до професійної медичної освіти.

of the American Medical Association. - 2004. - N 291 (17), Vol. 21. - P. 39-40.

3. World Federation for Medical Education. Global standards for quality improvement. Postgraduate Medical Education. WFME 2003. - Режим доступу : http:// wfme.org/standards/pgme/20-quality-improvementinpostgraduate-medical-education-russian/file.

2. Beck, Andrew H. (2004). The Flexner report and the standardization of American medical education. The Journal of the American Medical Association. 291 (17): 21, 39-40.

3.World Federation for Medical Education. Global standards for quality improvement. Postgraduate Medical Education. WFME 2003 (2003). - Retrieved from http:// wfme.org/standards/pgme/20-quality-improvementinpostgraduate-medical-education-russian/file

Отримано 06.04.17

Електронна адреса для листування: office@nmapo.edu.ua 